\title{
THE ANTIOXIDANT ACTIVITY AND PHYTOCHEMICAL SCREENING OF ETHANOL EXTRACT, FRACTIONS OF WATER, ETHYL ACETATE, AND N-HEXANE FROM MISTLETOE TEA (SCURRULA ATROPURPUREA BL. DANS)
}

\author{
RESMI MUSTARICHIE ${ }^{1 *}$, DUDI RUNADI ${ }^{2}$, DANNI RAMDHANI ${ }^{1}$
}

${ }^{1}$ Department of Pharmaceutical Analysis and Medicinal Chemistry, Faculty of Pharmacy, Universitas Padjadjaran, Indonesia. ${ }^{2}$ Department of Biological Pharmacy, Faculty of Pharmacy, Universitas, Padjadjaran, Indonesia. Email: rmustarichie@yahoo.com

Received: 17 October 2016, Revised and Accepted: 27 October 2016

\section{ABSTRACT}

Objective: The aim of this study is to investigate antioxidant activity and phytochemical screening of ethanol extract, fractions of water, ethyl acetate, and n-hexane from mistletoe tea (Scurrula atropurpurea Bl. Dans).

Methods: Simplicia extracted using soxhlet equipment with $96 \%$ ethanol. Fractionation was conducted using liquid-liquid extraction using a solvent of water, ethyl acetate and n-hexane. Screening of phytochemical and antioxidant activity was performed against these fractions. Antioxidant activity was determined by 2,2-diphenyl-1-picrylhydrazyl method using ultraviolet-visible spectrophotometry with ascorbic acid as standard. Phytochemical screening was conducted based on the method of Farnsworth.

Results: The IC50 values of ethanol extract, water fraction, fraction of ethyl acetate, and n-hexane fraction were $21.92 \mathrm{ppm}, 89.57 \mathrm{ppm}, 14.08 \mathrm{ppm}$, and $162.09 \mathrm{ppm}$, respectively, whereas for ascorbic acid was $4.41 \mathrm{ppm}$. The ethanol extract and ethyl acetate fraction contained compounds were the same group, polyphenolic, tannins, flavonoids, monoterpenoid, steroids, triterpenoids, and quinones. Fraction of water contained compounds such as polyphenolic group, flavonoids, monoterpenoids, sesquiterpenoids, steroids, and triterpenoids. n-hexane fraction compounds contained steroids and triterpenoids.

Conclusion: The ethanol extract, water fraction, ethyl acetate fraction, and n-hexane fraction showed antioxidant activities. The ethanol extract, fractions of water, and ethyl acetate fraction contained flavonoids and polyphenolic potential as antioxidants.

Keywords: Mistletoe tea, Scurrula atropurpurea, Antioxidant, 2,2-diphenyl-1-picrylhydrazyl, Ascorbic acid.

(c) 2016 The Authors. Published by Innovare Academic Sciences Pvt Ltd. This is an open access article under the CC BY license (http://creativecommons. org/licenses/by/4. 0/) DOI: http://dx.doi.org/10.22159/ajpcr.2016.v10i2.15724

\section{INTRODUCTION}

On the one hand, mistletoe is a plant which is unique because it is a parasitic plant that can be used as medicine [1]. Ohashi et al. [2] reported that the alkynic fatty acid octadeca-8, 10, 12-triynoic acid found as chemical constituents of Scurrula atropurpurea (Loranthaceae), a parasitic plant of the tea plant Thea sinensis (Theaceae), exhibited potent inhibitory effect on cancer cell invasion in vitro. It said the S. atropurpurea included 16 bioactive materials comprising six fatty acid compounds, two xanthine, two flavonol glycosides, monoterpene glycosides, one lignan glycosides, and four flavones. The tea mistletoe also traditionally used to decrease high blood pressure [3], antimicrobial activities against four bacterial strains (Bacillus subtilis, Klebsiella pneumoniae, Vibrio cholerae, and Escherichia coli) [4]. Mistletoe preparations have been used medicinally in Europe for centuries to treat epilepsy, infertility, hypertension, and arthritis $[5,6]$.

Degenerative disease and cancer can be inhibited when the bodie's own antioxidants as neutralizing free radicals [7]. There are two kinds of antioxidants: The natural and synthetic antioxidants. Natural antioxidant commonly found in plants such as fruits, grains, and vegetables. Some natural antioxidant compounds are derivatives of phenol, coumarin, hydroxycinnamic, tocopherol, diphenol, flavonoids, dihydroflavon, catechin, and ascorbic acid. Synthetic antioxidants include butyl hydroxylanisol, butyl hidroxytoluen, propyl gallate, ethoxyquin [8]. Activity mistletoe tea inhibit the oxidative damage caused by free radicals associated with the active ingredient in the leaves and stems of plants in the form of alkaloids, flavonoids, glycosides, triterpenoids, saponins and tannins [9].
This paper reports the activities of antioxidant and phytochemical screening of the ethanol extract, fractions of water, ethyl acetate and n-hexane from tea parasite (S. atropurpurea). S. atropurpurea used in this research was actually parasite tea as well as the methods used in the form of a modification of the existing methods with the application of different chemicals as well. It is worth mentioning here that in the Indonesian market there are two types of parasite tea is traded, namely S. atropurpurea and Dendrophthoe pentandra. D. pentandra is actually a parasite mango instead of tea parasite [10].

\section{METHODS}

Plant material

The leaves of mistletoe tea (S. atropurpurea) which had been dried and obtained from the Manoko Experimental Farm, Lembang, West Java, and determined in Taxonomy Laboratory, Department of Biology, Faculty of Mathematics and Natural Sciences, Universitas Padjadjaran.

\section{Extraction}

The extraction procedure was soxhletation method [11-13] guided by Herbal Pharmacopoeia of Indonesia [14]. Extraction based on crude material weighed and then extracted by soxhletation until the liquid contained in the tube soxhlet clear. Then, the extract was concentrated using a rotary evaporator and freeze-dried. The viscous extract obtained was defined its water content. Determination of the water content of the extract was carried out by adding $200 \mathrm{~mL}$ of toluene into a flask which already contains $2 \mathrm{mg}$ of the extract and then reheated. 


\section{Fractionation}

Fractionation of mistletoe tea was carried out by liquid-liquid extraction method (ECC). Certain amount extract obtained was dissolved in $200 \mathrm{~mL}$ of water and then put into a separating funnel and added n-hexane at an amount equal to the first solvent. Then, it was shaken with occasional air inside the funnel issued. Fraction of $n$-hexane and water fractions were separated. Extraction was repeated to obtain a fraction of n-hexane which was almost colorless. Into the layer of water was then added the same amount of ethyl acetate and shaken as above. A layer of n-hexane, ethyl acetate, and water that has been separated then evaporated with a rotary evaporator.

\section{Phytochemical screening}

Phytochemical screening conducted by the Farnsworth method [15]. Screening was done on the ethanol extract, the water fraction, fraction of ethyl acetate and n-hexane to screen the secondary metabolites such as alkaloids, polyphenols, tannins, flavonoids, monoterpenoid and sesquiterpenoids, quinones, triterpenoids and steroids, and saponins.

\section{Thin layer chromatography (TLC)}

TLC was carried out based on the modified method of Kumar et al. [16]. Extract and each fractions were spotted on a silica plate sized $4 \mathrm{~cm} \times 10$ $\mathrm{cm}$ by the upper limit and lower limit of $1 \mathrm{~cm}$ so that the developer within $8 \mathrm{~cm}$. A mixture of toluene:ethyl acetate:acetic acid (5:4:1) was prepared as a developer. Developers put in a chamber and allowed to saturate. Once saturated, silica plate inserted and allowed to touch the developer of the deadline. Plat silica observed in visible light, ultraviolet (UV) $254 \mathrm{~nm}$ and $366 \mathrm{~nm}$, and with 2,2-diphenyl-1-picrylhydrazyl (DPPH) reagent.

\section{Determination of free radical DPPH scavenging}

Antioxidant activity was carried out based on the modification of standard DPPH method $[17,18]$, in which DPPH solution was prepared with a concentration of $40 \mathrm{ppm}$. DPPH maximum wavelength and specified operating time DPPH in ethanol was determined. DPPH:ethanol (3:2) its absorbance was measured using UV-Vis spectrophotometer every 5 minutes for 120 minutes. The ethanol extract, fractions of water, and the ethyl acetate fraction were made at a concentration of 2, 4, 6, 8 , and $10 \mathrm{ppm}$. n-hexane fraction was made at a concentration of 20 , $40,60,80$, and $100 \mathrm{ppm}$. Vitamin C as a comparison was made with a concentration of 1, 2, 3, 4, and $5 \mathrm{ppm}$. Each test solution and reference mixed with DPPH, with a ratio of DPPH:sample (3:2). Once mixed, let the mixture stand for operating time DPPH in the test solutions, then the mixture was measured at UV-Vis spectrophotometry at wavelengths that has been obtained. From the absorbance obtained, percentage inhibition and regression curves were made, and the linear equation was applied to calculate the IC50.

\section{RESULTS AND DISCUSSION}

\section{Extraction}

The extraction of mistletoe tea ( $300 \mathrm{~g}$ ) by soxhletation with $96 \%$ ethanol obtained viscous extract of $23.8 \mathrm{~g}$ with a yield of $11.90 \%$. The water content in the mistletoe tea obtained at $4.98 \%$. The water content was set to maintain the quality of the extract. Based on farmakope herbal Indonesia [19], the water content in the extract should not be more than $10 \%$ which aims to avoid the rapid growth of fungi and microorganisms in the extract.

\section{Fractionation}

Fractionation ethanol extract of mistletoe tea with a liquid-liquid extraction method obtained three fractions of water fraction, fraction of ethyl acetate, and $\mathrm{n}$-hexane fraction of the weight of each condensed fraction $4.51 \mathrm{~g}, 2.31 \mathrm{~g}$, and $2.7 \mathrm{~g}$. The percentage yield of the water fraction, the fraction of ethyl acetate, and $\mathrm{n}$-hexane fraction were $2.255 \%, 1.155 \%$, and $1.35 \%$, respectively.

\section{Phytochemical screening}

Phytochemical screening results are shown in Table 1. The Scurrula species has not been extensively studied in terms of its phytochemistry [6]. Flavonols to be present in the Scurrula species reported by three articles [20-22]. Lohézic-Le Dévéhat et al. [23] successfully isolated three flavonols from Scurrula ferruginea: Quercetin, quercitrin, and 4"-O-acetylquercitrin, and the latter acetylated derivative was uncommon in higher plants. Priyanto et al. [24] declared an ethanol extract of $S$. atropurpurea consisting of flavonoids quercetin. Suspected quercetin was expressed using the color reagent magnesium powder, $\mathrm{HCl}$, and added amyl alcohol and red, yellow, or orange forms on amyl alcohol showed flavonoids. This reaction is actually a pointer reaction for flavonoid in phytochemical screening.

This research revealed that the ethanol extract, fractions of water, and the ethyl acetate contained flavonoids and polyphenol potential as antioxidants. This assumption in-line with others that majority of antioxidant compounds present in plants are secondary metabolitesphenolic compounds (tannins, flavonoids, and phenolic acids) which exhibit their protective properties through scavenging free radicals [25-27]. In addition to phenolics, plants may also contain antioxidant volatile oils, carotenoids, and vitamins [28].

\section{TLC}

Results of TLC using developer: Toluene: ethyl acetate: acetic acid (5:4:1) are shown in Fig. 1. Unlike this research, Krisnawati [29] used two-dimensional paper chromatography to isolate flavonoid from ethanolic extract with butanol: acetic acid: water (3:1:1). The partial structure of flavonoid was determined by spectroscopy UV-visible with different diagnostic reagent.

Fig. 1 shows that the ethanol extract, fraction of ethyl acetate, and n-hexane fraction had three spots while the water fraction had one spot. On the results of TLC with DPPH reagent, the color changes to yellow with purple background color indicated the presence of compounds that have antioxidant activity. In extracts of ethanol, water fraction, fraction of ethyl acetate, and n-hexane fraction, visible yellow color of the compound spotted with purple background meaning that extracts and fractions contain compounds that have antioxidant activity. Profile of each spots and Rf value of chromatography results is shown in Table 2.

\section{Antioxidant activity with DPPH method}

The antioxidant activity of the extracts and fractions mistletoe tea was carried by 1,1-diphenyl-2 picrylhydrazyl using a UV-visible spectrophotometer. DPPH molecule is stable free radical molecules in the presence of electron delocalization around the molecule. Before testing the antioxidant activity, we carried out prior determination of the maximum wavelength of DPPH solution and determination of operating time DPPH solution in $96 \%$ ethanol. It aimed to determine the best time and stable work of DPPH solution. From the result of the determination of the maximum wavelength obtained, DPPH maximum

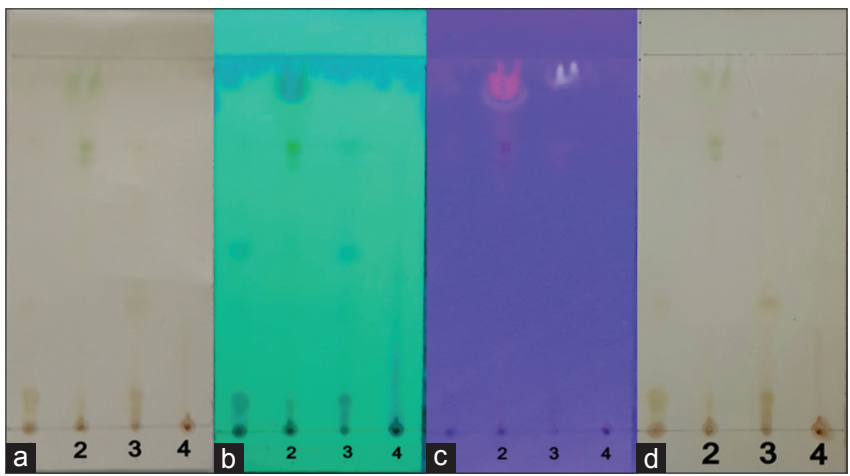

Fig. 1: Thin layer chromatography of mistletoe tea developer toluene:ethyl acetate:acetic acid (5:4:1). (1) Ethanol extract, (2) water fraction, (3) ethyl acetate fraction, (4) n-hexane fraction. (a) With visible light, (b) with ultraviolet (UV) $254 \mathrm{~nm}$, (c) with UV $366 \mathrm{~nm}$, (d) with 2, 2-diphenyl-1-picrylhydrazyl reagent 
Table 1: Phytochemical screening of $S$. atropurpurea

\begin{tabular}{|c|c|c|c|c|c|c|}
\hline S. No. & Secondary metabolite & Simplicia & Ethanol extract & Water fraction & Ethyl acetate fraction & n-hexane fraction \\
\hline 1 & Alkaloids & - & - & - & - & - \\
\hline 2 & Polyphenols & + & + & + & + & - \\
\hline 3 & Tannins & + & + & - & + & - \\
\hline 4 & Flavonoids & + & + & + & + & - \\
\hline 5 & Monoterpenoid and sesquiterpenoids & + & + & + & + & - \\
\hline 6 & Steroids & + & + & + & + & + \\
\hline 7 & Triterpenoids & + & + & + & + & + \\
\hline 9 & Saponins & - & - & - & - & - \\
\hline
\end{tabular}

Table 2: TLC profile of Scurrula atropurpurea

\begin{tabular}{|c|c|c|c|c|c|c|}
\hline Sample & Spotting number & Rf value & Visible light & UV $254 \mathrm{~nm}$ & UV 366 nm & DPPH reagent \\
\hline \multirow[t]{3}{*}{ Ethanol extract } & 1 & 0.08 & Brown & Purple & - & Yellow \\
\hline & 2 & 0.5 & - & Purple & - & Yellow \\
\hline & 3 & 0.93 & - & Purple & Purple & Yellow \\
\hline Water fraction & 1 & 0.95 & - & Purple & Purple & - \\
\hline \multirow[t]{3}{*}{ Ethyl acetate fraction } & 1 & 0.06 & Brown & Purple & Green & Yellow \\
\hline & 2 & 0.75 & - & Yellow & Red & Yellow \\
\hline & 1 & 0.94 & Brown & Purple & - & Yellow \\
\hline \multirow[t]{2}{*}{ n-hexane fraction } & 2 & 0.75 & Brown & Purple & Purple & Yellow \\
\hline & 3 & 0.95 & - & Purple & Green & - \\
\hline
\end{tabular}

S. atropurpurea: Scurrula atropurpurea, DPPH: 2, 2-diphenyl-1-picrylhydrazyl, UV: Ultraviolet, TLC: Thin layer chromatography

Table 3: Percentage of mistletoe tea extract, fractions and vitamin $\mathrm{C}$

\begin{tabular}{|c|c|c|c|}
\hline Sample & Concentration (ppm) & Absorbance & $\%$ inhibition \\
\hline \multirow{5}{*}{$\begin{array}{l}\text { Ethanol } \\
\text { extract }\end{array}$} & 10 & 0.3997 & 21.29 \\
\hline & 8 & 0.4245 & 16.4 \\
\hline & 6 & 0.4465 & 12.07 \\
\hline & 4 & 0.4677 & 7.857 \\
\hline & 2 & 0.4997 & 1.595 \\
\hline \multirow{5}{*}{$\begin{array}{l}\text { Water } \\
\text { fraction }\end{array}$} & 80 & 0.3862 & 43.47 \\
\hline & 40 & 0.5167 & 24.37 \\
\hline & 20 & 0.6131 & 10.26 \\
\hline & 10 & 0.6468 & 5.328 \\
\hline & 5 & 0.6787 & 0.658 \\
\hline \multirow{5}{*}{$\begin{array}{l}\text { Ethyl } \\
\text { acetate } \\
\text { fraction }\end{array}$} & 10 & 0.4365 & 34.38 \\
\hline & 8 & 0.4755 & 28.52 \\
\hline & 6 & 0.5146 & 22.64 \\
\hline & 4 & 0.5673 & 14.71 \\
\hline & 2 & 0.6279 & 5.607 \\
\hline \multirow{5}{*}{$\begin{array}{l}\text { n-hexane } \\
\text { fraction }\end{array}$} & 100 & 0.6347 & 31.56 \\
\hline & 80 & 0.703 & 24.2 \\
\hline & 60 & 0.769 & 17.08 \\
\hline & 40 & 0.8074 & 12.94 \\
\hline & 20 & 0.8695 & 6.243 \\
\hline \multirow[t]{5}{*}{ Vitamin C } & 5 & 0.2274 & 57.27 \\
\hline & 4 & 0.2924 & 45.06 \\
\hline & 3 & 0.3531 & 33.65 \\
\hline & 2 & 0.4191 & 21.25 \\
\hline & 1 & 0.4698 & 11.72 \\
\hline
\end{tabular}

wavelength was $517 \mathrm{~nm}$. From the measurement of operating time, DPPH in ethanol $96 \%$ was obtained within DPPH best work from the $35^{\text {th }}$ minute until the $50^{\text {th }}$ minute. The curve of operating time DPPH solution in $96 \%$ ethanol is shown in Fig. 2.

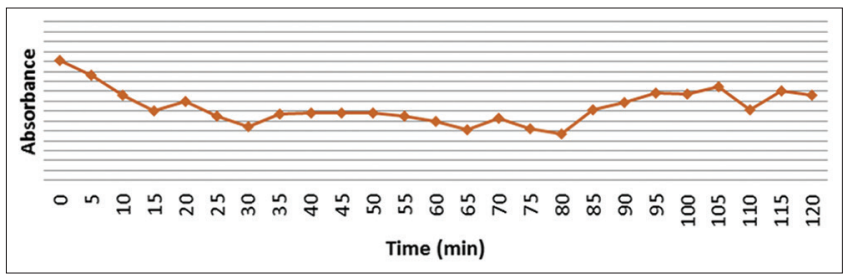

Fig. 2: Operating time of 2, 2-diphenyl-1-picrylhydrazyl solution in $96 \%$ ethanol

Before sample absorbance measurement, the test sample and the reference solution were incubated beforehand in DPPH solution of $40 \mathrm{ppm}$. The measurement results for the sample incubation time in the ethanol extract of DPPH solution was 30 minutes, the water fraction of 40 minutes, 30 minutes ethyl acetate fraction, n-hexane fraction of 45 minutes, and vitamin C 30 minutes. In testing the antioxidant activity with DPPH methods, parameters used for interpretation antioxidant activity was the IC50. IC50 values were calculated from the linear regression equation that states the relationship between the concentration of the sample (X-axis) and the percent inhibition (Y-axis) showing a 50\% reduction activity DPPH concentration. Percentage inhibition was calculated from the reduction of arithmetic DPPH absorbance with the absorbance of the sample.

\%inhibition $=\left[1-\left(\frac{\text { Asample, } \text { mean }}{\text { ADPPH }}\right)\right] \times 100$

Data from \% inhibition of the extract, fractions, and a comparison of vitamin $\mathrm{C}$ against DPPH solution are shown in Table 3.

Table 4 shows the calculated antioxidant activity of ethanol extract and the third fraction of mistletoe tea and vitamin $\mathrm{C}$.

According to Jun et al., as well as other text books [30,31] antioxidant activity is categorized as a very powerful when IC50 $<50 \mathrm{ppm}$, strong if IC50 values of 50-100 ppm, moderate at 101-250 ppm, and 
Table 4: Results of measurement of antioxidant activity

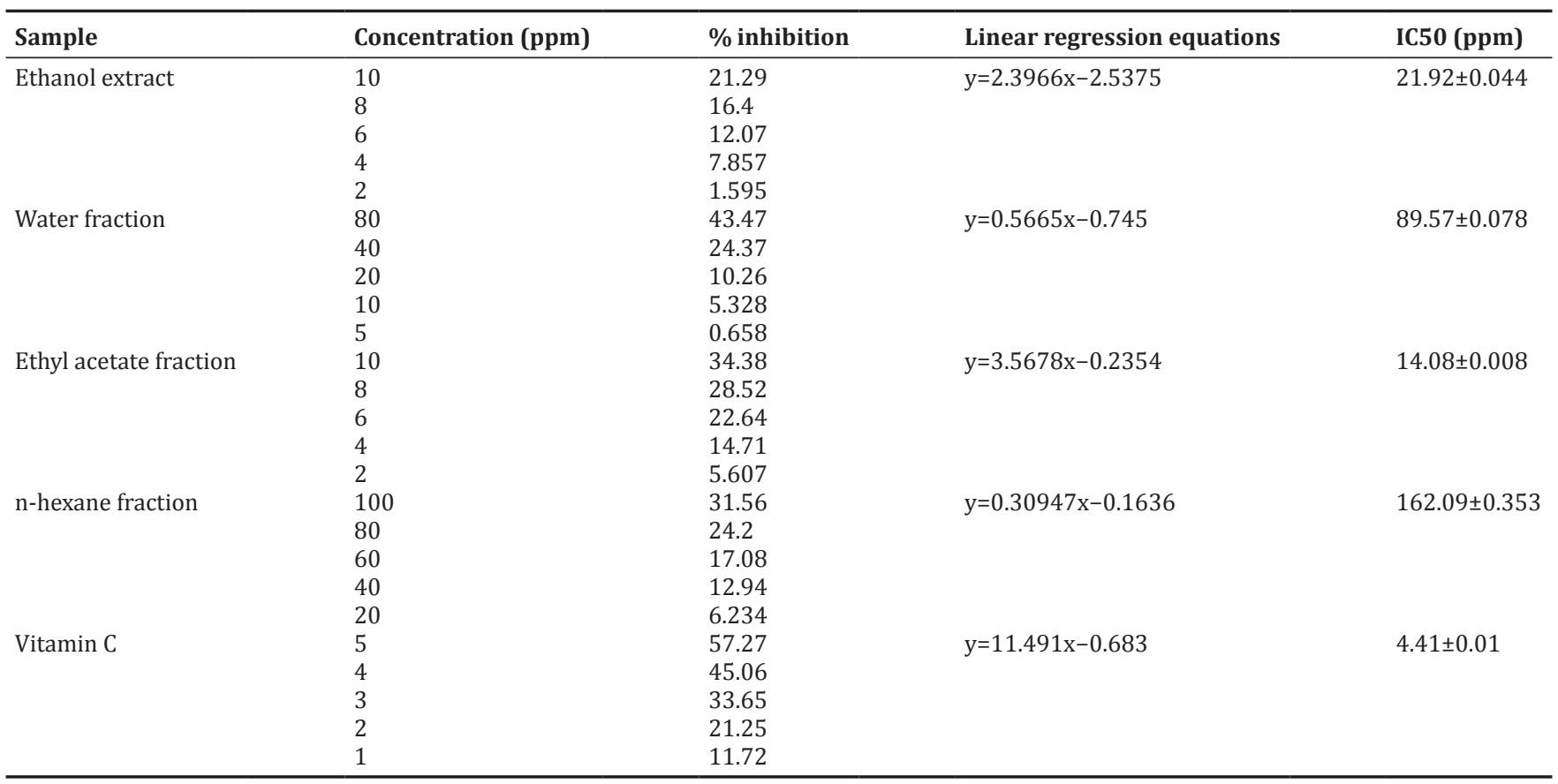

weak when IC50 250-500 ppm, and classified as inactive when the IC50 $>500$ ppm.

The antioxidant activity of the test results on mistletoe tea samples, obtained IC50 to extract ethanol, water fraction, fraction of ethyl acetate, n-hexane fraction was $21.92 \mathrm{ppm}$ (category very strong), $89.57 \mathrm{ppm}$ (strong category), $14.08 \mathrm{ppm}$ (category very strong), and $162.09 \mathrm{ppm}$ (medium category), while for the comparison of vitamin C obtained IC50 of $4.41 \mathrm{ppm}$ (very strong category). It was found that the necessary concentration of ethyl acetate fraction small to capture $50 \%$ of free radicals than those of the ethanol extract, the water fraction, and the fraction of n-hexane. Ethyl acetate fraction which had the smallest IC50 was $14.08 \mathrm{ppm}$ so that it could be said ethyl acetate fraction had the greatest antioxidant activity compared with other test samples because it required a concentration of about $14.08 \mathrm{ppm}$ to dampen the activity of DPPH radicals by $50 \%$, but still three times weaker than with vitamin C with IC50 of $4.41 \mathrm{ppm}$. The IC50 value was owned by a fraction of n-hexane with IC50 of $162.09 \mathrm{ppm}$, which meant the fraction of $n$-hexane had the smallest antioxidant activity compared with other test samples. In general, a compound having bioactivity as polyphenol antioxidant was a compound class that had a hydroxy group. Polyphenolic compounds inhibit free radicals by way of donating protons and form a stable radical. The formation of a stable radical was because free electrons contained in the radical stabilized by electron delocalization in the presence of resonance on the aromatic ring. In addition, a compound thought to have antioxidant activities such as polyphenolic compounds, flavonoids, and quinones. In studies of mistletoe tea, leaves have got the result that the highest antioxidant activity contained in ethyl acetate fraction. This is because in general polyphenols and flavonoids are polar, so it would be easy to dissolve in the fraction with a polar solvent or semi-polar, so that the fraction of n-hexane non polar compounds of flavonoids did not extract perfectly that cannot reduce the activity of radical DPPH maximally. Besides polyphenols and flavonoids, according Suhartono and Setiawan [32], quinone compounds and derivatives also have antioxidant activity due to its ability as an electron acceptor. This is consistent with the results of phytochemical screening the ethanol extract, fractions of water, and the ethyl acetate fraction, indicating that all three samples contain compounds that have antioxidant activity, namely, polyphenols, flavonoids, and quinones. Therefore, ethanol extract and ethyl acetate fraction by IC50 has antioxidant activity in the category very strong and the water fraction have antioxidant activity with strong category, whereas the fraction of n-hexane has antioxidant activity in the category of weak due to phytochemical screening does not contain compounds polyphenol, flavonoids, or quinones and only contain steroids and triterpenoids. Athiroh and Sulistyowati [33], however, used different method in determination of antioxidant activity of tea parasite $S$. atropurpurea leaf extract claimed to get strong antioxidant with an IC50 of $11.64 \%$. These researchers used methanol and $515 \mathrm{~nm}$ wavelength instead.

\section{CONCLUSIONS}

The results showed that ethanol extract, the water fraction, fraction of ethyl acetate, and n-hexane fraction of mistletoe tea leaves have antioxidant activity. This is indicated by the IC50 value that is owned by the ethanol extract and each fraction. Best antioxidant activity contained in ethyl acetate fraction with IC50 value was 14.08 ppm (very strong), followed by the ethanol extract of IC50 value of $21.92 \mathrm{ppm}$ (very strong), the fraction of water with IC50 value of $89.57 \mathrm{ppm}$ (very strong), and the fraction of n-hexane with IC50 value of $162.09 \mathrm{ppm}$ (average), while the IC50 value of vitamin C was $4.41 \mathrm{ppm}$ (very strong). There is room for further research, that is to find a compound in the ethyl acetate fraction which is responsible for its antioxidant activity.

\section{ACKNOWLEDGMENT}

We would like to thank Fadli Apriliandi for his technical assistance.

\section{REFERENCES}

1. Soejono. Host Parasite Tea Tree Inventory in Purwodadi Botanical Garden. Seminar Kelompok Kerja Nasional Tumbuhan Obat Indonesia IX 21-22 September, 1995. Indonesia: Universitas Gadjah Mada; 1995.

2. Ohashi K, Winarno H, Mukai M, Inoue M, Prana MS, Simanjuntak P, et al. Indonesian medicinal plants. XXV. Cancer cell invasion inhibitory effects of chemical constituents in the parasitic plant Scurrula atropurpurea (Loranthaceae). Chem Pharm Bull (Tokyo) 2003;51(3):343-5.

3. Kwanda N, Noikotr K, Sudmoon R, Tanee T, Chaveerach A. Medicinal parasitic plants on diverse hosts with their usages and barcodes. J Nat Med 2013;67(3):438-45

4. Tripathi S, Ray S, Das PK, Mondal AK, Verma NK. Antimicrobial activities of some rare aerial hemi parasitic taxa of South West Bengal, 
India. Int J Phytopharmacol 2013;4(2):106-12

5. Pandya N. Facts \& comparisons 4.0. J Med Libr Assoc 2007;95(2):217-9.

6. Lim YC, Rajabalaya R, Lee SH, Tennakoon KU, Le QV, Idris A, et al. Parasitic mistletoes of the genera Scurrula and Viscum: From bench to bedside. Molecules 2016;21(8). pii: E1048.

7. Poumorad F, Hosseinimehr SJ, Shahabimajd N. Antioxidant activity phenol and flavonoud contents of some selected Iranian medical plants. Afr J Biotechnol 2006;5(11):1142-5.

8. Dalimartha S. Atlas Indonesian Medicinal Plants. Jilid 1. Jakarta: Trubus Agriwidya; 1999. p. 146-9.

9. Windari FI, Rahajoe JS. Diversity of species of parasites on the Island of Java. Indonesian medicinal plants news. J Indones Med Plant 1998;4(4):25-9.

10. Litz RE. The Mango: Botany, Production and Uses. $2^{\text {nd }}$ ed. Cambridge, MA: CABI; 2009. p. 269.

11. Mustarichie R, Indriyati W, Mukmin A, Ramdhani D. Activity of Angiopteris evecta for baldness treatment. J Chem Pharm Res 2016;8(5):821-30.

12. Gatbonton GL, De Jesus AP, Lorenzo KM, Uy MM. Soxhlet Extraction of Philippine Avocadro Fruit Pulp Variety 240, Presented at the Research Congress 2013 De La Salle University Manila March 7-9; 2013.

13. Marnoto T, Haryono G, Gustinah D, Putra FA. The extraction of tannins as natural dyes from plants putrimalu (Mimosa pudica) using an organic solvent. Reaktor 2012;14(1):39-45

14. Departement Kesehatan RI. Indonesian Herbal Pharmacopea, Edisi I. Jakarta: Departement Kesehtaan RI; 2015. p. 17-8.

15. Farnsworth NR. Biological and phytochemical screening of plant. J Pharm Sci 1966;55(3):243-69.

16. Kumar S, Jyotirmayee K, Sarangi M. Thin layer chromatography: A tool of biotechnology for isolation of bioactive compounds from medicinal plants. Int J Pharm Sci Rev Res 2013;18(1):126-32.

17. Mustarichie R, Udin Z, Muhtadi A, Surahman E, Subarnas A, Supriyatna $\mathrm{S}$. The antioxidant activity and cytotoxicity methanol extracts from cranberry plants. Int Res J Pharm Appl Sci 2012;2(4):56-61.

18. Garcia EJ, Oldoni TL, Alencar SM, Reis A, Loguercio AD, Grande RH. Antioxidant activity by DPPH assay of potential solutions to be applied on bleached teeth. Braz Dent J 2012;23(1):22-7.

19. Departement Kesehatan RI. Indonesian Herbal Pharmacopea. Jakarta:
Departement Kesehatan RI; 2008.

20. Shen CC, Chang YS, Hott LK. Nuclear magnetic resonance studies of 5, 7-dihydroxyflavonoids. Phytochemistry 1993;34:843-5.

21. Shibuya H, Ohashi K, Kitagawa I. Search for pharmacological leads from tropical rainforest plants. Pure Appl Chem 1999;71(6):1109-13.

22. Ishizu T, Tsujino E, Winarno H, Ohashi K, Shibuya H. A complex of perseitol and $\mathrm{K}+$ ion from Scurrula fusca (Loranthaceae). Tetrahedron Lett 2001;42(39):6887-9.

23. Lohézic-Le Dévéhat F, Tomasi S, Fontanel D, Boustie J. Flavonols from Scurrula ferruginea danser (Loranthaceae). Z Naturforsch C 2002;57(11-12):1092-5.

24. Priyanto JA, Pujiyanto S, Rukmi I. Flavonoids production capability test of mistletoe tea (Scurrula atropurpurea BL. Dans) endophytic bacteria isolates. J Sainsdan Mat 2014;22(4):89-96.

25. Kähkönen MP, Hopia AI, Vuorela HJ, Rauha JP, Pihlaja K, Kujala TS, et al. Antioxidant activity of plant extracts containing phenolic compounds. J Agric Food Chem 1999;47:3954-62.

26. Cai Y, Luo Q, Sun M, Corke H. Antioxidant activity and phenolic compounds of 112 traditional Chinese medicinal plants associated with anticancer. Life Sci 2004;74:2157-84.

27. Dai J, Mumper RJ. Plant phenolics: Extraction, analysis and their antioxidant and anticancer properties. Molecules 2010;15:7313-52.

28. Marvibaigi M, Amini N, Supriyanto E, Jamil S, MajidFA, Jaganathan SK, et al. Total phenolic content, antioxidant and antibacterial properties of Scurrula ferruginea extracts. J Teknol 2014;5:65-72.

29. Krisnawati M. Isolation and identification of flavonoid compounds from parasite tea leaves (Scurrula atropurpurea Dans); 2010. Available from: http://www.zonaresearch.blogspot.co.id/2010/09/isolasi-danidentifikasi-senyawa.html.

30. Jun M, Fu HY, Hong J, Wan X, Yang CS, Ho CT. Comparison of antioxidant activities of isoflavones from kudzu root (Pueraria labata Ohwi). J Food Sci Technol 2003;68(6):2117-22.

31. Shahidi F. Natural Antioxidant: Chemistry, Health Effects, and Applications. USA: AOCS; 1997.

32. Suhartono E, Setiawan B. Oxidative stress and antioxidant role in diabetes mellitus. Majalah Kedokt Indones 2005;55(2):86.

33. Athiroh NA, Sulistyowati E. Scurrula atropurpurea increases nitric oxide and decreases malondialdehyde in hypertensive rats. Univ Med 2013;32(1):44-50 